\title{
LOCAL VANCOMYCIN IN PREVENTION OF SURGICAL SITE INFECTION IN SPINAL SURGERIES
}

\author{
Hany Nabil El zahlawy, Zakaria Hassan Ibrahim, and \\ Gadallah Helal Gadallah
}

\begin{abstract}
Orthopaedic Surgery Department, Faculty of Medicine, Ain Shams University, Cairo, Egypt. Corresponding author Gadallah Helal Gadallah Mobile: (+2) 01274939175 E.mail: gadhela19@gmail.com

Received: $12 / 1 / 2021$

Accepted: 3/2/2021
\end{abstract}

Online ISSN: 2735-3540

\begin{abstract}
:
Background: SSIs can lead to greater post-operative morbidity, mortality and healthcare costs. Despite current prophylactic measures, SSIs is still being reported in patients undergoing spine surgery. Local application of vancomycin in spine surgery is a lowcost strategy to help reduce SSIs as it is active against pathogens which might contaminate the wound during spinal surgery.
\end{abstract}

Aim of the Work: A systematic review discussing the effect of Local vancomycin in prevention of surgical site in spinal surgeries.

Patients and Methods: Literature search and filtration on intrawound application of vancomycin in spinal surgeries yielded 9 studies with a total of 46,907 patients.

Results: Review of the enrolled studies confirmed that intrawound vancomycin use appears to be safe and effective for reducing postoperative SSIs in spinal surgeries with a low rate of adverse events. However, these studies use different definitions for surgical site infections and different pre-, peri- and postoperative antibiotic regimens. That is why intra wound application of vancomycin in spinal surgeries is recommended to reduce postoperative SSIs and further studies using standardized protocols are needed to confirm findings of the current study.

Conclusion: The different follow-up periods, particularly for patients with short-term follow up, may underestimate the incidence of SSIs and adverse events especially in the vancomycin group.

Keywords: Local Vancomycin, Surgical Site Infection, Spinal Surgeries

\section{INTRODUCTION:}

Deep surgical site infections (SSIs) are a substantial burden to the patient and the health-care system. Despite the ubiquity of prophylactic antibiotics and aseptic technique, SSIs comprise $22 \%$ of all health care-related infections and are the second most common health care-associated infections in the United States ${ }^{(\mathbf{1})}$.

The literature has demonstrated significant morbidity with SSIs after spinal fusion procedures ${ }^{(2)}$, as well as adult spinal trauma $^{(3)}$, and the short- and long-term effects of SSI can be devastating. Multiple reoperations, instrumentation removal, longterm antibiotic therapy, and prolonged hospital stays complicate the postoperative period, negatively impact patient reported outcomes and hospitalization costs increase significantly when these complications occur $^{(\mathbf{4})}$. With increasing pressures to control resource utilization, and the curtailed reimbursement for the treatment of "preventable", complications, it is imperative that additional techniques to 
control SSIs and minimize these costs be discovered $^{(\mathbf{5})}$.

Traditionally, perioperative prophylaxis for SSIs during spine surgery has included intravenous antibiotic coverage of Grampositive organisms, such as a 1st generation cephalosporin or clindamycin, given within 1 hour prior to surgical incision and discontinued within 24 hours following the end of surgery ${ }^{(6 \& 7)}$. Cephalosporins have been preferentially used because of high activity against Gram positive organisms, particularly Staphylococcus aureus, which is the most common cause of SSIs. S. aureus has been identified as the causative organism in $30 \%$ of all SSIs reported to the National Healthcare Safety Network between 2006 and 2008, including approximately 50\% of all orthopaedic and neurosurgical procedures ${ }^{(\boldsymbol{8})}$. However, rising resistance to common antibiotic medications has led to ineffective prophylaxis against more than half of all SSI causing organisms; methicillin-resistant $S$. aureus SSIs have seen a significant increase in frequency and are notoriously difficult to treat ${ }^{(\mathbf{9 7 1 0})}$.

Because of these concerns, various studies have reported placement of lyophilized vancomycin powder directly into the surgical wound during closure as a form of perioperative antibiotic prophylaxis ${ }^{(11)}$. In doing so, the direct inoculation of the site with high concentrations of the antibiotic will hypothetically overwhelm any residual bacterial load, even those with moderate resistance, and will ultimately decrease the rate of SSIs. Intrasite application of the drug should also theoretically minimize rapid absorption into the systemic circulation, thereby reducing vancomycin-associated side effects ${ }^{(12)}$.

It is also hypothesized that the precipitous concentration gradient between the local wound and the supporting circulation should also curtail the generation of drug resistance ${ }^{(13)}$.
Vancomycin is a glycopeptide antibiotic (branched tricyclic glycosylated non ribosomal peptide, C66H75Cl2N9O24) produced by the Actinobacteria species Amycolatopsis orientalis and was first isolated in 1953 by Edmund Kornfeld from a soil sample collected in Borneo. Vancomycin was derived from the term "vanquish," and the original indication was for the treatment of penicillin-resistant $S$. aureus.

The bactericidal mechanism of action of vancomycin is inhibition of cell wall biosynthesis in Gram-positive bacteria and occurs through various methods: inhibits RNA synthesis and formation of long polymers for the bacterial cell wall, for any long polymers that do form, prevents them from cross-linking with each other, and alters bacterial cell membrane permeability ${ }^{(14)}$.

Vancomycin is not active against Gramnegative bacteria (except some nongonococcal species of Neisseria) because they produce their outer membrane and cell walls by a different mechanism. The US Food and Drug Administration (FDA) in 1958 first approved the use of IV vancomycin (initial trade name Vancocin; Eli Lilly, Indianapolis, IN, USA) for the treatment of penicillin-resistant Staphylococci infections and is now widely available in generic versions ${ }^{(15)}$.

The current topic regarding the use of vancomycin as an intrasite adjunct within a surgical wound uses the IV preparation, which is produced as a white-to-tan lyophilized powder. The unreconstituted lyophilized powder is available in singledose vials produced by various generic manufacturers and typically contains equivalents of $500 \mathrm{mg}, 750 \mathrm{mg}$, or $1 \mathrm{~g}$. Most importantly, the intrasite administration of vancomycin powder has not been approved by the US FDA and requires investigational new drug approval before initiating a prospective study evaluating this treatment ${ }^{(16)}$. 


\section{AIM OF THE WORK:}

A systematic review discussing the effect of Local vancomycin in prevention of surgical site in spinal surgeries.

\section{MATERNAL AND METHODS:}

This systematic review consisted of 4 steps, including a systematic search of the literature (Step 1), selection of studies (Step 2 ), recording of study characteristics (Step 3 ) and extraction of data on clinical outcomes and their comparisons between different surgical groups (Step 4).

\section{Step 1: Data sources and search strategy:}

The literature search was performed according to PRIMSA guidelines using the following electronic databases: The Cochrane database of systematic reviews, the Cochrane central register of controlled trials, PubMed and MEDLINE as database for search. The search strategy included several different terms and synonyms for local vancomycin, prevention of surgical site infections in spinal surgeries.

\section{Step 2: Selection of studies and screening of titles and abstracts:}

First, all titles and abstracts were screened for the following criteria:

- Article concerned: prospective randomizes trials as well as both prospective and retrospective cohort studies.

\section{- Inclusion criteria:}

1. Clinical studies reporting the use of local vancomycin in prevention of surgical site infections in spinal surgeries.

2. Studies included patients with any type of spine pathology treated (degenerative, trauma, tumor and deformity) undergoing spine surgery (decompression, instrumented, or noninstrumented procedures) in any region of the spine (i.e., cervical, thoracic, and/or lumbar)

3. English literature.

\section{- Exclusion criteria:}

1. Case reports, comments, letters, guidelines, protocols, abstracts and review papers.

2. Studies with unclear reporting of methods or results.

3. Animal and cadaveric studies.

\section{Step 3: Study characteristics:}

The following study characteristics were systematically extracted from the selected full-text papers: authors, year of publication, study design, the number of patients, mean age and duration of the follow-up, dose and placement of vancomycin, outcome measures (SSI incidence, types of bacteria, adverse event rate).

\section{Step 4: Outcomes of the included studies:}

Outcome characteristics (incidence of SSIs, types of bacteria, adverse events rate) were systematically extracted from the selected full-text papers.

The initial literature search identified 74 articles which were assessed for possible inclusion. $1^{\text {st }}$ screening of titles and abstracts excluding duplicates and articles not in English language is done 20 articles were identified for 2 nd screening. $2^{\text {nd }}$ screening of the full articles for study characteristics meeting the inclusion criteria is done and 9 articles were included. A schematic representation of literature extraction process is shown in figure (1). 


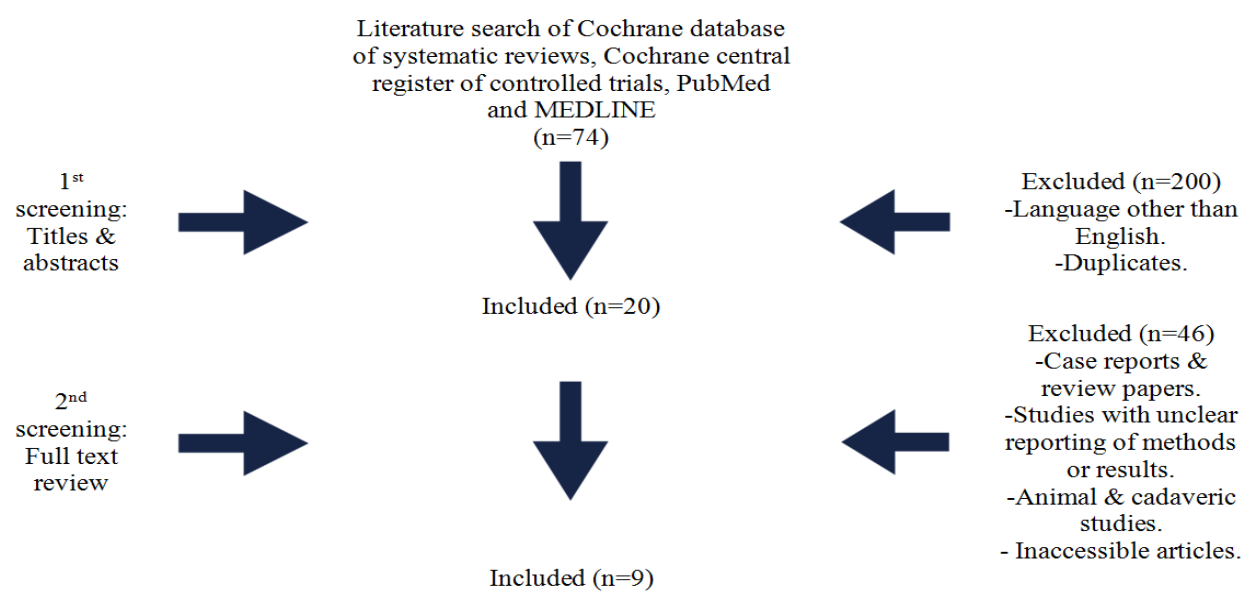

Figure 1: Flowchart of study design

\section{RESULTS:}

Nine full text articles (46,907 patients) were included in our final analysis. Table (1) shows the summary of the design of the included studies, while the baseline characteristics of these studies are illustrated in Table (2). Meanwhile, the dose and placement of vancomycin are shown in table (3).

Table 1: Summary of study design of included studies.

\begin{tabular}{|c|c|c|c|}
\hline Authors & Year & Journal & Type of the study \\
\hline Bakhsheshian et al. & 2015 & World Neurosurgery & $\begin{array}{l}\text { Systematic review and meta- } \\
\text { analysis }\end{array}$ \\
\hline Ghobrial et al. & 2015 & Neurosurgery Focus & Systematic review \\
\hline Schroeder et al. & 2016 & European Spine Journal & Retrospective comparative \\
\hline Hida et al. & 2017 & Nagoya Journal of Medical Science & Retrospective comparative \\
\hline Xie et al. & 2017 & Orthopedic Surgery & $\begin{array}{l}\text { Systematic review and meta- } \\
\text { analysis }\end{array}$ \\
\hline Horii et al. & 2018 & The Spine Journal & Prospective comparative \\
\hline Lemans et al. & 2019 & Global Spine Journal & $\begin{array}{l}\text { Systematic review and meta- } \\
\text { analysis }\end{array}$ \\
\hline Adhikari et al. & 2020 & Asian Spine Journal & Retrospective comparative \\
\hline Takeuchi et al. & 2020 & $\begin{array}{c}\text { European Journal of Orthopedic Surgery and } \\
\text { Traumatology }\end{array}$ & Retrospective comparative \\
\hline
\end{tabular}

Table 2: Baseline characteristics of included studies

\begin{tabular}{|c|c|c|c|c|}
\hline Authors & No of patients & $\begin{array}{c}\text { No. of VCM treated } \\
\text { patients }\end{array}$ & $\begin{array}{c}\text { Mean age of patients } \\
\text { (years) }\end{array}$ & $\begin{array}{c}\text { Period of follow up } \\
\text { (months })\end{array}$ \\
\hline Bakhsheshian et al. & 6383 & NR & NR & $1-20$ \\
\hline Ghobrial et al. & 9721 & 6701 & NR & NR \\
\hline Schroeder et al. & 3477 & 1224 & $\begin{array}{r}56.3 \pm 13.2 \text { in VCM gp. } \\
57.1 \pm 14.5 \text { in controls }\end{array}$ & $\begin{array}{c}20.4 \pm 6.5 \text { in VCM gp. } \\
22.5 \pm 6.6 \text { in controls }\end{array}$ \\
\hline Hida et al. & 174 & 81 & $49 \pm 23$ & $3-30$ \\
\hline Xie et al. & 15499 & 7331 & NR & $3-24$ \\
\hline Horii et al. & 2859 & 694 & NR & NR \\
\hline Lemans et al. & 7968 & 3439 & $49.31 \pm 22.77$ in VCM gp. & $50.77 \pm 22.47$ in controls \\
\hline Adhikari et al. & 158 & 88 & $69.2(\mathrm{R}: 25-89)$ in VCM gp. & 68.1 (R:16-89) in controls \\
\hline Takeuchi et al. & 668 & 314 & & 1.5 \\
\hline
\end{tabular}

* VCM, Vancomycin; NR, Not reported; gp., group; R, Range 


\section{Local Vancomycin In Prevention Of Surgical Site Infection In Spinal Surgeries}

Table 3: Dose and placement of vancomycin in the vancomycin groups

\begin{tabular}{|c|c|c|}
\hline Authors & Dose & Vancomycin placement \\
\hline Schroeder et al. & $1-1.5$ grams & Covering all layers of the wound \\
\hline Hida et al. & 1 gram & Application on wound and bone grafts \\
\hline Horii et al. & 1 or 2 grams & Spread throughout the wound \\
\hline Adhikari et al. & 1 gram & Application on muscles, fascia and subcutaneous tissues \\
\hline Takeuchi et al. & 1 gram & $\begin{array}{c}\text { Direct application to the entire wound including bone, } \\
\text { muscle and subcutaneous tissue }\end{array}$ \\
\hline
\end{tabular}

Table (4) show the incidence of SSIs in vancomycin and control groups.

Table 4: Incidence of SSIs in vancomycin and control groups.

\begin{tabular}{|c|c|c|c|}
\hline Authors & SSIs in VCM group & SSIs in control group & P value \\
\hline Ghobrial et al. & $1.36 \%$ & $7.47 \%$ & NR \\
\hline Schroeder et al. & $0.41 \%$ & $1.33 \%$ & 0.04 \\
\hline Hida et al. & $0 \%$ & $4.3 \%$ & NR \\
\hline Horii et al. & $1.73 \%$ & $0.97 \%$ & 0.10 \\
\hline Lemans et al. & $1.1 \%$ & $4.2 \%$ & $<0.0001$ \\
\hline Adhikari et al. & $3.4 \%$ & $1.4 \%$ & 0.431 \\
\hline Takeuchi et al. & $0.3 \%$ & $2.5 \%$ & 0.01 \\
\hline Bakhsheshian et al. & $\begin{array}{c}\text { Odds of developing deep infection with intra wound vancomycin } \\
\text { powder compared to without vancomycin powder = 0.23 }\end{array}$ & 0.0002 \\
\hline Xie et al. & $\begin{array}{c}\text { Odds of developing deep infection without intra wound vancomycin } \\
\text { powder compared to with vancomycin powder = 2.83 }\end{array}$ & 0.083 \\
\hline
\end{tabular}

* VCM, Vancomycin; NR, Not reported

Table 5: Microbiology reports of infected cases

\begin{tabular}{|c|c|c|c|c|}
\hline \multirow{2}{*}{ Authors } & \multicolumn{4}{|c|}{ Pathogenic bacteria } \\
\hline & \multicolumn{3}{|c|}{ In the vancomycin group } & In the control group \\
\hline Schroeder et al. & \multicolumn{3}{|c|}{ P.acnes, E.coli, MRSA, MSSA } & $\begin{array}{c}\text { MSSA, MRSA, Staphylococcus coagulase } \\
\text { negative, P.acnes, E.coli, Gram-negative bacteria }\end{array}$ \\
\hline Hida et al. & \multicolumn{3}{|c|}{---} & E.coli, MRSE, MRSA \\
\hline Horii et al. & \multicolumn{3}{|c|}{$\begin{array}{c}\text { MSSA, MRSA, MRCNS, } \\
\text { P.aeruginosa, E.faecalis, Anaerobic } \\
\text { gram-negative bacilli }\end{array}$} & $\begin{array}{c}\text { MSSA, MSCNS, MRSA, MRCNS, P.aeruginosa, } \\
\text { Enterobacter cloacae, Finegoldia magna, Gram- } \\
\text { positive bacilli }\end{array}$ \\
\hline Adhikari et al. & \multicolumn{3}{|c|}{ E.coli, P.aeruginosa } & Morganella morganii, S. epidermidis \\
\hline Takeuchi et al. & \multicolumn{3}{|c|}{ P.aeruginosa } & MSSE, S.marcescens, MRSA \\
\hline \multicolumn{5}{|c|}{$\begin{array}{l}\text { P.acnes, Propionibacterium acnes; E.coli, Escherichia coli; MRSA, Methicillin-resistant } \\
\text { staphylococcus aureus; MSSA, Methicillin-susceptible staphylococcus aureus; MRSE, Methicillin- } \\
\text { resistant staphylococcus epidermidis; MRCNS, Methicillin-resistant coagulase negative staphylococci; } \\
\text { P.aeruginosa, Pseudomonas aeruginosa; E.faecalis, Enterococcus faecalis; MSCNS, Methicillin- } \\
\text { susceptible coagulase negative staphylococci; S.epidermidis, Staphylococcus epidermidis; } \\
\text { S.marcescens, Serratia marcescens }\end{array}$} \\
\hline \multicolumn{5}{|c|}{ Table 6: Reported overall adverse events rate } \\
\hline Authors & $\begin{array}{l}\text { No. of } \\
\text { events }\end{array}$ & Overall rate & & Adverse events reported (No. of patients) \\
\hline Ghobrial et al. & $23 / 6701$ & $0.3 \%$ & & $\begin{array}{l}\text { ropathy (1), ototoxicity with transient hearing loss } \\
\text { 2), systematic absorption with supratherapeutic } \\
\text { ncomycin exposure (1), culture-negative seroma } \\
\text { formation (19) }\end{array}$ \\
\hline Hida et al. & 0 & $0 \%$ & & --- \\
\hline Lemans et al. & 0 & $0 \%$ & & --- \\
\hline Adhikari et al. & 0 & $0 \%$ & & --- \\
\hline
\end{tabular}




\section{DISCUSSION:}

Surgical site infections "SSIs" were defined as infections occurring up to 30 days after surgery (or up to one year after surgery in patients receiving implants) and affecting either the incision or deep tissue at the operation site ${ }^{(\mathbf{1 6})}$. SSIs are considered the most frequently reported health acquired infection and common surgical complication in both developed as well as developing countries $^{(17)}$.

SSIs following spine surgery comprise superficial and deep infections. Superficial spine infections are localized to the skin and subcutaneous tissue. On the other hand, deep infections disseminate under the fascia and encompass discitis, epidural abscess and spondylitis $^{(\mathbf{1 8})}$.

SSIs can lead to greater post-operative morbidity, mortality and healthcare costs. Despite current prophylactic measures, SSIs is still being reported in patients undergoing spine surgery ${ }^{(\mathbf{2 3})}$.

The use of intra-wound vancomycin is rapidly being adopted for the prevention of SSIs in spinal surgery ${ }^{(23)}$. The poularity of its use can be attributed to its protective effects as well as its lower $\operatorname{cost}^{(24)}$. At operative closure, vancomycin powder is placed in the wound bed, in addition to the standard infection prophylaxis, and this can provide high concentrations of antibiotics with minimal systemic absorption ${ }^{(22)}$.

And despite the limited availability of high-quality evidence in the literature, intra wound vancomycin has been considerably used by spine surgeons, mainly in spine surgeries involving instrumentation such as revision procedures, trauma and deformity $^{(27)}$.

Vancomycin is most often used as intra wound antibiotic prophylaxis because of its potency to treat infections with grampositive skin commensals such as
Staphylococcus aureus and Staphylococcus epidermidis $^{(\mathbf{2 4})}$. The benefits of using intra wound vancomycin include the ability to achieve a significantly higher MIC in the wound bed, while minimizing the serum concentration of the drug; therefore lowering its systemic absorption ${ }^{(\mathbf{1 9})}$.

However, several studies have reported contradictory findings regarding the use of intra wound vancomycin in modern spinal surgery practices ${ }^{(\mathbf{2 3})}$.

The purpose of this systematic review was to discuss the effect of local vancomycin in prevention of SSIs in spinal surgeries.

Literature search and filtration yielded 9 studies (4 retrospective, 3 meta-analyses, 1 prospective, 1 systematic review) with a total of 46,907 patients.

The current review revealed that intra wound vancomycin administration in a dose of 1-2 grams resulted in significant reduction of SSIs in spinal surgeries. Meanwhile, the rate of SSIs in the vancomycin group was higher than that in the control group in two of the included studies ${ }^{(30,31)}$. However, the difference was not statistically significant. Furthermore, this was only found in the whole cohort but when analysis of the matched cohorts was performed, the incidence of SSIs was lower in the vancomycin group than in the control group $(\mathrm{p}=0.81)^{(\mathbf{3 0})}$.

Decreases in SSI caused by methicillinresistant S.aureus and methicillin-resistant S.epidermidis as a result of application of vancomycin were previously reported ${ }^{(29)}$. The application of vancomycin led to a decrease in the percentage of the SSI pathogenic bacterium $S$. aureus ${ }^{(35)}$. These results indicated decreases in sensitive grampositive bacteria in surgical wounds as a result of application of vancomycin, which in turn leads to decreases in SSI caused by vancomycinsensitive Staphylococcus strains. 
These results also suggested that the total number of SSI incidents decreased ${ }^{(\mathbf{3 4})}$.

The effect of vancomycin powder in the prevention of deep SSIs was revealed in a meta-analysis of 18 papers with an odds ratio of $0.23(95 \% \text { CI } 0.11-0.50)^{(23)}$. Several previous studies ${ }^{(\mathbf{3 3}, 36,37)}$ have also reported that intra wound vancomycin use is safe and effective for decreasing postoperative SSI rates.

A retrospective study, performed on 174 consecutive patients who underwent spine surgery in whom vancomycin powder was administered in the wound before closing wound in the vancomycin group, revealed that deep SSI was not observed in the vancomycin group, whereas it was observed in 4 patients in the control group. However, no side effects were observed in any of the cases. However, this study had several limitations. Firstly, patients' background information and surgical interventions were different between the vancomycin and control groups. In addition, there was a large selection bias. The surgeons tended to use vancomycin in cases where the risk of infection was high. Another limitation was the small number of subjects used in the study, and the result was that the statistical power was not high enough to compare the occurrence of SSIs between the two groups. Nevertheless, the authors concluded that the intra wound administration of vancomycin might be effective to prevent SSI in cases with high risks of infection ${ }^{(20)}$.

On the other hand, Tubaki et al. reported that local application of vancomycin to surgical wounds did not significantly reduce the incidence of infection after spine surgery in a randomized controlled study (28). However, this study was limited by the lack of power analysis and a low infection rate (1.61-1.68\%), which indicated that the risk of developing an infection was relatively low ${ }^{(20)}$.
These findings indicate that intra wound administration of vancomycin was effective in reduction of SSIs in spinal surgeries.

Review of microbiology reports of infected cases in the studies enrolled in the current review revealed that pathogenic bacteria in vancomycin group were mostly vancomycin-resistant supporting the efficacy of vancomycin.

Similarly, a recently published study based on operative wound drainage tube culture revealed that SSI occurred significantly less often in the vancomycin than in the control group and this was not associated with any adverse drug effects. However, the incidence of positive culture of vancomycin-resistant bacteria was not decreased by vancomycin. Importantly, pathogenic bacteria in the vancomycin group were only vancomycin-resistant, supporting the efficacy of vancomycin. However, it was impossible to rule out the possibility of contamination of drainage tube cultures during the testing procedure which may account for the presence of positive and negative reports on the accuracy of drainage tube culture and this is considered as a limitation of the study. Other limitations of the study were its retrospective nature in addition to the incompletely matched patient backgrounds in the two groups. The authors concluded that the local application of vancomycin decreases the amount of bacteria in the operative field and leads to fewer SSIs. They believed that its use is worth considering owing to the extremely low risk of adverse drug effects associated with its use and considering the difficulties associated with treating SSI ${ }^{(34)}$.

The current review revealed that the reported overall adverse event rate following intrawound administration of vancomycin revealed a very minimal incidence of adverse events, if any, supporting the safety of its use. 
Similarly, one of the largest case series with intra wound vancomycin use in 1512 surgeries reported 1 case of transient renal failure. While all patients received $1 \mathrm{~g}$ vancomycin, the time course of renal failure, the changes in creatinine over time and the serum concentrations of vancomycin were unclear ${ }^{(32)}$. Prior studies showed that serum vancomycin rarely increases to supratherapeutic levels after intra wound administration and is nearly undetectable after 24 hours. Also, intra wound vancomycin use did not result in any side effects ${ }^{(31)}$. No adverse events attributable to intra wound vancomycin were found in a meta-analysis; however, the authors also stated that the current quality of evidence was low ${ }^{(21)}$.

A retrospective study on vancomycin use reported that there was one outlier in which supratherapeutic vancomycin levels were noted without any systemic toxicity (25). Furthermore, both serum vancomycin and creatinine levels were evaluated and no significant rise in either laboratory value across 87 pediatric patients undergoing spinal deformity surgery was found ${ }^{(25)}$.

A recent systematic review found only one case of adverse drug reaction (transient rash) in almost 1400 children undergoing posterior spinal surgery for early onset scoliosis, a rate of only $0.072 \%{ }^{(38)}$. In addition, patients in this study who had previously shown adverse drug reactions to intravenous vancomycin did not react to intra wound vancomycin powder ${ }^{\text {(24). }}$.

A more recent systematic review and meta-analysis enrolled 20 articles were included ( 2 randomized controlled trials and 18 observational studies). Sixteen studies investigated the use of intra wound antibiotics and 4 studies investigated the use of intra wound antiseptics. This systematic review and meta-analysis revealed a positive effect of perioperative intra wound prophylaxis to reduce the risk of SSI, with a relative risk of 0.26 (95\% CI $0.16-0.44$ ) compared with no intra wound treatment.
When viewed separately, both antibiotics and antiseptics were significantly effective with relative risks of 0.29 (*3 times lower risk) and 0.14 (*7 times lower risk), respectively ${ }^{(24)}$. Similar results were found in a systematic review of 8 studies ${ }^{(21)}$.

The current review has several limitations. First, most of the included studies were retrospectively designed, which may have selection bias. Second, study disparities and limitations in size, different definitions of SSIs, different designs with different followup periods, different treatment protocols and outcome measures, contribute significant bias. Third, patient co-morbidities have not been provided by most of the studies, which is an important confounder that affects the incidence of SSIs following surgery. Finally, the different follow-up periods, particularly for patients with short-term follow up, may underestimate the incidence of SSIs and adverse events especially in the vancomycin group.

\section{REFERENCES}

1. Chiang HY, Herwaldt LA, Blevins AE, Cho E, Schweizer ML. Effectiveness of local vancomycin powder to decrease surgical site infections: a meta-analysis. Spine J 2014; 14:397-407.

2. Mok JM, Guillaume TJ, Talu U, Berven SH, Deviren V, Kroeber M, et al. Clinical outcome of deep wound infection after instrumented posterior spinal fusion: a matched cohort analysis. Spine 2009;34: 578-83.

3. Lonjon G, Dauzac C, Fourniols E, Guigui P, Bonnomet F, Bonnevialle P. Early surgical site infections in adult spinal trauma: a prospective, multicentre study of infection rates and risk factors. Orthop Traumatol Surg Res 2012; 98:788-94.

4. Graf K, Ott E, Vonberg RP, Kuehn C, Schilling T, Haverich A, et al. Surgical site infections - economic consequences for the health care system. Langenbecks Arch Surg 2011;396:453-9. 


\section{Local Vancomycin In Prevention Of Surgical Site Infection In Spinal Surgeries}

5. Centers for Medicare and Medicaid Services (CMS) HHS. Medicaid program; payment adjustment for providerpreventable conditions including health care-acquired conditions. Final rule. Fed Regist 2011; 76:32816-38.

6. Olsen MA, Nepple JJ, Riew KD, Lenke LG, Bridwell KH, Mayfield J, et al. Risk factors for surgical site infection following orthopaedic spinal operations. J Bone Joint Surg Am 2008;90:62-9.

7. Van Middendorp DJ, Pull Ter Gunne DA, Drmed PM, Cohen DD, Hosman DA, van Laarhoven PC. A methodological systematic review on surgical site infections following spinal surgery. Part 2: prophylactic treatments. Spine 2012;37: 2034-45.

8. Hidron AI, Edwards JR, Patel J, Horan TC, Sievert DM, Pollock DA, et al. NHSN annual update: antimicrobial-resistant pathogens associated with healthcareassociated infections: annual summary of data reported to the National Healthcare Safety Network at the Centers for Disease Control and Prevention, 2006- 2007. Infect Control Hosp Epidemiol 2008;29:9961011.

9. Anderson DJ, Sexton DJ, Kanafani ZA, Auten G, Kaye KS. Severe surgical site infection in community hospitals: epidemiology, key procedures, and the changing prevalence of methicillin-resistant Staphylococcus aureus. Infect Control Hosp Epidemiol 2007;28: 1047-53.

10. Klevens RM, Edwards JR, Richards CL Jr, Horan TC, Gaynes RP, Pollock DA, et al. Estimating health care-associated infections and deaths in U.S. hospitals, 2002. Public Health Rep 2007;122: 160-6.

11. Molinari RW, Khera OA and Molinari WJ III. Prophylactic intraoperative powdered vancomycin and postoperative deep spinal wound infection: 1,512 consecutive surgical cases over a 6-year period. Eur Spine J. 2012;21(Suppl 4):S476-S482.
12. Sweet FA, Roh M, Sliva C. Intrawound application of vancomycin for prophylaxis in instrumented thoracolumbar fusions: efficacy, drug levels, and patient outcomes. Spine 2011;36:2084-8.

13. Lazar HL, Barlam T, Cabral H. The effect of topical vancomycin applied to sternotomy incisions on postoperative serum vancomycin levels. J Card Surg 2011;26:461-5.

14. Levine DP. Vancomycin: a history. Clin Infect Dis 2006;42 (1):S5-12.

15. Caroom C, Tullar JM, Benton EG Jr, Jones JR, Chaput CD. Intrawound vancomycin powder reduces surgical site infections in posterior cervical fusion. Spine 2013;38:1183-7.

16. Zebala LP, Chuntarapas T, Kelly MP, Talcott M, Greco S, Riew KD. Intrawound vancomycin powder eradicates surgical wound contamination: an in vivo rabbit study. J Bone Joint Surg Am 2014;96: 4651.

17. Centers for Disease Control and prevention "CDC". Surgical site infection (SSI). 2010. Accessed on 25-5-2020 from: https://www.cdc.gov/ hai/ssi/ssi.html

18. Mukagendaneza MJ, Munyaneza E, Muhawenayo E, Nyirasebura D, Abahuje E et al. Incidence, root causes and outcomes of surgical site infections in a tertiary care hospital in Rwanda: A prospective observational cohort study. Patient Safety in Surgery. 2019; 13:10.

19. Schroeder JE, Girardi FP, Sandhu H, Weinstein J, Cammisa FP et al. The use of local vancomycin powder in degenerative spine surgery. Eur Spine J. 2016;25:102933.

20. Smith JS, Shaffrey CI, Sansur CA, Berven $\mathrm{SH}, \mathrm{Fu} \mathrm{KG}$ et al. Rates of infection after spine surgery based on 108,419 procedures. Spine. 2011;36:556-63.

21. Widmer AF, Rotter M, Voss A, Nthumba P, Allegranzi $B$ et al. Surgical hand preparation: State-of-the-art. J Hosp Infect. 2010;74(2):112-22. 


\section{Hany Nabil El zahlawy, et al.,}

22. Mueller TC, Loos M, Haller B, Mihaljevic $\mathrm{AL}$, Nitsche $\mathrm{U}$ et al. Intra-operative wound irrigation to reduce surgical site infections after abdominal surgery: A systematic review and meta-analysis. Langenbeck's Arch Surg. 2015; 400(2):167-81.

23. van Meurs SJ, Gawlitta D, Heemstra KA, Poolman RW, Vogely HC et al. Selection of an optimal antiseptic solution for intraoperative irrigation: An in vitro study. $\mathbf{J}$ Bone Joint Surg Am. 2014; 96:285-91.

24. Sweet FA, Roh M and Sliva C. Intrawound application of vancomycin for prophylaxis in instrumented thoracolumbar fusions: Efficacy, drug levels and patient outcomes. Spine (Phila Pa 1976). 2011;36:2084-8.

25. Xie L, Zhu J, Yang M, Yang C, Luo S et al. Effect of intra-wound Vancomycin for spinal surgery: A systematic review and meta-analysis. Orthopedic Surgery. 2017; 9(4):350-8.

26. Lemans JVC, Wijdicks SPJ, Boot W, Govaert GAM, Houwert RM et al. Intrawound treatment for prevention of surgical site infections in instrumented spinal surgery: A systematic comparative effectiveness review and meta-analysis. Global Spine Journal. 2019;9(2):219-30.

27. Sweet F, Sliva C and Roh M. Intra-wound application of vancomycin for prophylaxis in instrumented thoracolumbar fusions. Spine J. 2009;9:5S.

28. Soriano A, Marco F, Martinez JA, Pisos E, Almela $\mathrm{M}$ et al. Influence of vancomycin minimum inhibitory concentration on the treatment of methicillin-resistant Staphylococcus aureus bacteremia. Clin Infect Dis. 2008; 46(2):193-200.

29. Heller A, McIff TE, Lai SM and Burton DC. Intrawound vancomycin powder decreases staphylococcal surgical site infections after posterior instrumented spinal arthrodesis. J Spinal Disord Tech. 2015;28:E584-E589.
30. Horii C, Yamazaki T, Oka H, Azuma S, Ogihara $S$ et al. Does intrawound vancomycin powder reduce surgical site infection after posterior instrumented spinal surgery? A propensity score-matched analysis. The Spine Journal. 2018; 18:220512.

31. Adhikari P, Nabiyev VN, Bahadir S, Ayhan $S$, Yuksel $S$ et al. Does the application of topical intrawound Vancomycin powder affect deep surgical site infection and the responsible organisms after spinal surgery?: A retrospective case series with a historical control group. Asian Spine J. 2020; 14(1): 72-8.

32. Molinari RW, Khera OA and Molinari WJ III. Prophylactic intraoperative powdered vancomycin and postoperative deep spinal wound infection: 1,512 consecutive surgical cases over a 6-year period. Eur Spine J. 2012;21(Suppl 4):S476-S482.

33. Martin JR, Adogwa O, Brown CR, Bagley $\mathrm{CA}$, Richardson WJ et al. Experience with intrawound vancomycin powder for spinal deformity surgery. Spine (Phila Pa 1976). 2014; 39:177-84.

34. Takeuchi H, Oda I, Oshima S, Suzuki M and Fujiya M. Is the administration of vancomycin to operative field effective? Studying from operative wound drainage tube culture. European Journal of Orthopaedic Surgery \& Traumatology. 2020;30:215-9.

35. Chotai S, Wright PW, Hale AT, Jones WA, McGirt MJ et al. Does intrawound vancomycin application during spine surgery create vancomycin resistant organism? Neurosurgery. 2017;80(5):74653.

36. Chiang HY, Herwaldt LA, Blevins AE, Cho $\mathrm{E}$ and Schweizer ML. Effectiveness of local vancomycin powder to decrease surgical site infections: A meta-analysis. Spine J. 2014;14:397-407. 


\section{Local Vancomycin In Prevention Of Surgical Site Infection In Spinal Surgeries}

37. Xiong L, Pan Q, Jin G, Xu Y and Hirche C. Topical intrawound application of vancomycin powder in addition to intravenous administration of antibiotics: A meta-analysis on the deep infection after spinal surgeries. Orthop Traumatol Surg Res. 2014;100:785-9.
38. DeFrancesco CJ, Flynn JM, Smith JT, Luhmann SJ, Sawyer JR et al. Children's Spine Study Group. Clinically apparent adverse reactions to intrawound vancomycin powder in early onset scoliosis are rare. J Child Orthop. 2017;11(6):414-8.

\section{تأثير الفانكوميسين المجفف في الوقاية من عدوى الموقع الجراحي في العمليات الجراحيه في العمود الفقري، دراسه منهجيه الجون}

هاني نبيل الزحلاوي، ذكريا حسن ابراهيم، جاد الله هلال جاد الله

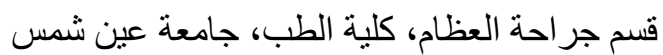

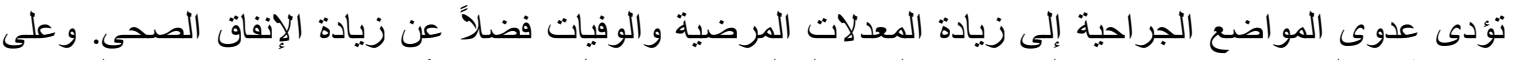

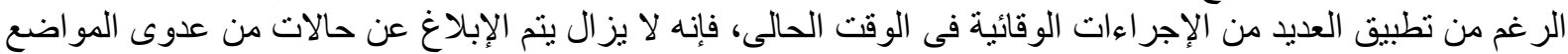

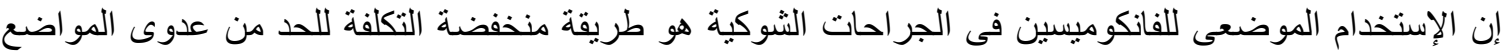

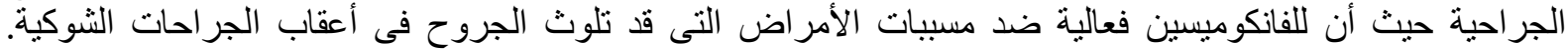

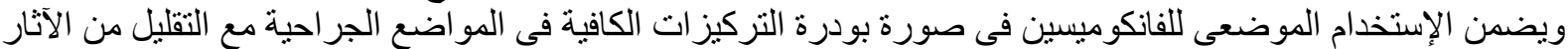

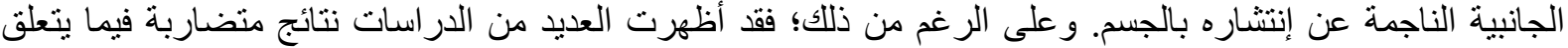

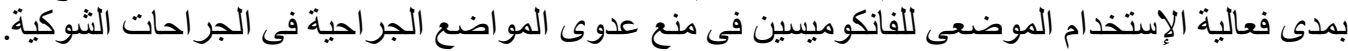
ولقد نتج عن البحث فى الدراسات السابقة إدر اج تسعة دراسات بحثية بخصوص الإستخدام الموضعى للفانكوميسين فى الجر احات الثوكية بإجمالى في النى 46907 مريضًا.

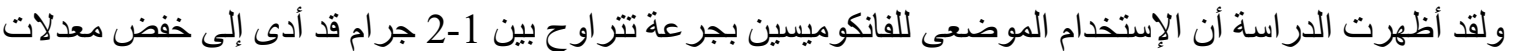

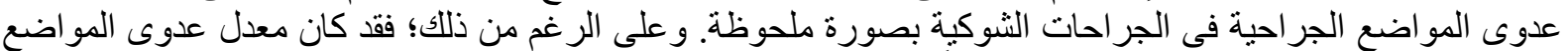

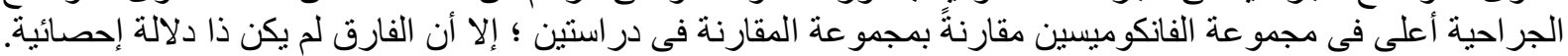

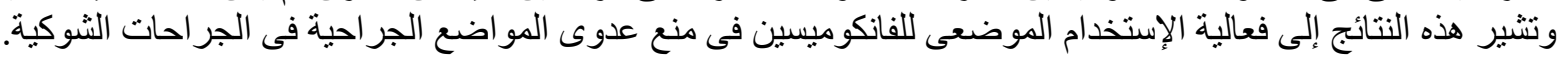

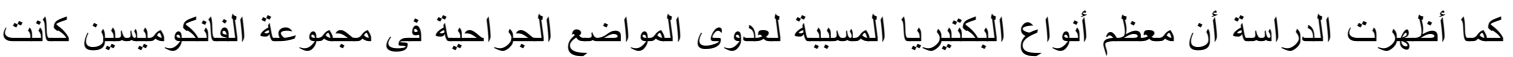
مقاومة للفانكو ميسين مما يؤكد فعالية الإستخدام الموضعى اللفانكو ميسين.

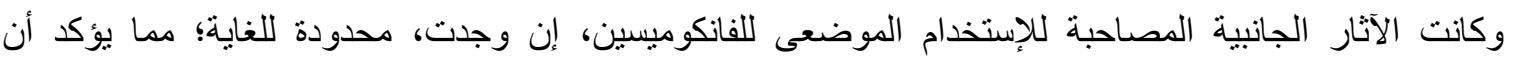
الإستخدام الموضعى للفانكوميسين آمن.

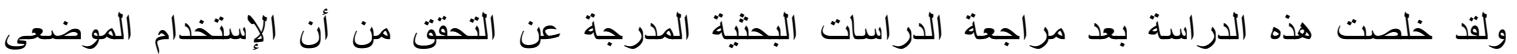

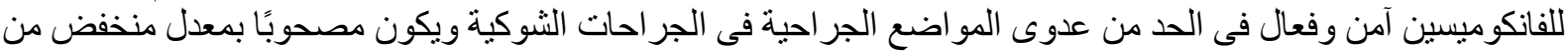

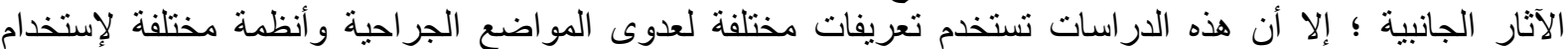
المضادات الحيوية قبل و أثناء وبعد إجر اء الجراء الجر احة.

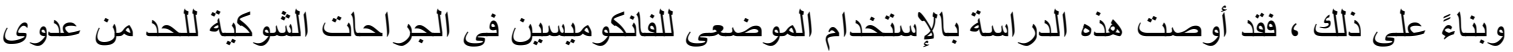
المواضع الجراحية مع إجراء المزيد من الدراسات البحثية بإستخدام بروتوكولات موحدة بهدف التحقق من نتائج هذه 